\title{
Absence of linkage between idiopathic dilated cardiomyopathy and candidate genes involved in the immune function in a large Italian pedigree
}

International Centre
for Genetic
Engineering and
Biotechnology,
AREA Science Park,
Padriciano 99, I-34012
Trieste, Italy
M Krajinovic
L Mestroni
G M Severini
B Pinamonti
A Falaschi
M Giacca
Division of
Cardiology,
Ospedale Maggiore
and University,
Piazza Ospedale 1,
I-34100 Trieste, Italy
L Mestroni
F Camerini
Correspondence to
Dr Giacca.
Received 6 January 1994
Revised version accepted for
publication 5 May 1994

\begin{abstract}
Idiopathic dilated cardiomyopathy (IDC) is a heart disease of unknown aetiology characterised by impaired ventricular function usually associated with dilatation of the cardiac chambers. In order to test the hypothesis of an immunological cause for the disease at the genetic level, we performed linkage analysis between the putative disease locus and some of the potential candidate genes involved in the immune response or coding for the targets for autoantibodies in a large multigeneration family (63 members) from southern Italy with autosomal dominant transmission of the disease. Twenty-nine polymorphic markers on 18 different chromosomal locations were investigated, including markers linked to the genes coding for the HLA antigens, the immunoglobulin heavy and light chains, the receptors for the immunoglobulin Fc fragments, the subunits of the $T$ cell receptor and the associated CD3, CD4, CD8, and CD45 antigens, interleukins $1,3,4,5,6,9$, and 11 , the interleukin 1 and 2 receptors, and the genes coding for the $\beta_{1}$ adrenoreceptor, the adenine nucleotide translocator- 1 , and the cardiac $\alpha$ and $\beta$ myosin heavy chains.

No evidence for genetic linkage to IDC was found at any of these candidate loci. These results indicate that the still unidentified IDC gene maps outside several loci involved in the regulation of immune reactivity.
\end{abstract}

(f Med Genet 1994;31:766-771)

Idiopathic dilated cardiomyopathy (IDC) is a chronic heart muscle disease of unknown aetiology, ${ }^{1}$ characterised by impaired systolic function usually associated with ventricular dilatation, with a prevalence of 36.5 affected persons per 100000 in the USA population. ${ }^{2}$ Progressive deterioration is common during the clinical course of the disease, with symptoms resulting from heart failure, low output state, and arrhythmia. The disease is usually associated with a very poor prognosis, ${ }^{34}$ and represents the major indication for heart transplantation in the world. ${ }^{5}$

The aetiology of the disease is unknown. A coxsackie virus type $B$ infection, with previous myocarditis and subsequent development of chronic myocardial damage, has long been considered. ${ }^{6}$ However, the search for enteroviral genomes in endomyocardial biopsies by the extremely sensitive polymerase chain reaction technique has led to disappointing results, allowing several groups, including ours, to rule out the persistence of these viruses in the myocardium as the major cause of the disease. ${ }^{7-9}$

Among the several pathogenetic hypotheses formulated, ${ }^{1011}$ the involvement of the immune system in the development of the disease is supported by the finding of several immunological abnormalities in patients with IDC, including decreased natural killer cell activity, ${ }^{12}$ functional deficit in suppressor cell activity, ${ }^{13}$ and cellular and humoral autoimmune reactivities against myocytes. ${ }^{14}$ In particular, an increased presence of organ specific autoantibodies against myocardial antigens has been shown in patients with IDC as compared to the normal population or control patients ${ }^{15}$; these autoantibodies are directed against several cardiac proteins including the $\alpha$ and $\beta$ cardiac myosin heavy chain isoforms, ${ }^{16}$ the $\beta_{1}$ adrenergic receptor, ${ }^{1718}$ the muscarinic acetylcholine receptor- $2,{ }^{19}$ and some mitochondrial antigens such as the $M 7^{20}$ and the adenine nucleotide translocator ${ }^{21}$ proteins. Whether these serological reactivities are the primary cause of the disease or represent specific markers of cardiac damage ${ }^{22}$ is not known at present.

Another indirect support to the hypothesis of the involvement of the immune system in the pathogenesis of the disease derives from several studies which evaluated the association of IDC with the presence of specific antigens of the major histocompatibility complex, in particular of class II, in patients with the disease. A positive association between IDC and HLA-DR4 has been described in several serological studies from different countries. ${ }^{23-26}$ Since class II antigens are involved in the presentation of foreign peptides to $\mathrm{T}$ helper lymphocytes, it is conceivable that an abnormal antigen presentation could lead to an autoimmune response. In addition, it has been shown that a specific IgG heavy chain constant region (Gm) phenotype is overrepresented in IDC patients compared with normal controls, and that a potentiating interactive effect is found between the $\mathrm{Gm}$ phenotype and HLA-DR4. ${ }^{27}$

Finally, an increasing number of patients 
with IDC (more than 20\%) has recently been acknowledged to be affected by the familial form of the disease, ${ }^{328}$ with different patterns of transmission. At present, it is not known whether the sporadic and the familial forms, which are indistinguishable by clinical and morphological criteria, represent different nosological presentations of the same disease.

The availability of DNA samples from members of families with IDC offers the possibility to study the genetic transmission of known chromosomal markers and to define their linkage to the disease. In this work, we investigated the linkage of the putative disease gene with several candidate genes involved in the immune function, as well as genes encoding some IDC autoantigens, in a large Italian family with IDC.

\section{Materials and methods}

\section{PATIENTS AND SAMPLES}

To avoid genetic heterogeneity, a single, large, four generation family from the south of Italy was used in this study. Sixty-three members (mean age 31 years) were clinically evaluated, six of whom were affected. Clinical, electrocardiographic, and echocardiographic assessments were performed as previously described. $^{311}$ The diagnosis of IDC was based on the demonstration of poor contractility of the left ventricle or of both ventricles, associated with dilatation of the cardiac chambers, in the absence of any known cause of myocardial disease. ${ }^{1}$ In this family, the disease is inherited as an autosomal dominant trait with age dependent penetrance.

DNA samples from each available member of the family were extracted by standard procedures $^{29}$ either from fresh blood samples or from continuous B lymphocyte cell lines immortalised with the Epstein-Barr virus. ${ }^{30}$

\section{MICROSATELLITE ANALYSIS}

Polymerase chain reaction (PCR) analysis was performed using highly polymorphic markers with a high percentage of heterozygosity (table), chosen for their localisation either intragenic or very close to the gene of interest, based on published chromosomal maps. ${ }^{4548}$ These chromosomal markers were constituted by di-, tetra-, or pentanucleotide polymorphisms (microsatellites), with the exception of the immunoglobulin heavy chain gene cluster, which was analysed by the study of a VNTR region. The references, locus, and name for each of the markers used are given in the table. The chromosomal locations of the candidate genes were based on data reported at the 11 th International Workshop on Human Gene Map-

Linkage of IDC to candidate genes involved in the immune function

\begin{tabular}{|c|c|c|c|c|c|c|}
\hline Gene & Location & Locus & Marker & $\theta_{t}$ & $\theta_{2}$ & $\operatorname{Ref}$ \\
\hline HLA & $6 \mathrm{p} 21.3$ & D6S265 & AFM101xa1 & 0.045 & 0.002 & 31 \\
\hline $\begin{array}{l}\text { Immunoglobulins and Fc receptors } \\
\text { Heavy chain (IGH) } \\
\text { Light chain } \kappa \text { (IGLK) } \\
\text { Light chain } \lambda \text { (IGLL) } \\
\text { Fc receptor for IgA, IgG, IgEI } \\
\text { Fc receptor for IgEII }\end{array}$ & $\begin{array}{c}14 \mathrm{q} 32.33 \\
2 \mathrm{p} 12 \\
22 \mathrm{q} 11.1-11.2 \\
1 \mathrm{q} 23 \\
19 \mathrm{p} 13.3\end{array}$ & $\begin{array}{l}\text { IGHJ } \\
\text { CD8A } \\
\text { D22S275 } \\
\text { D1S104 } \\
\text { LIPE }\end{array}$ & $\begin{array}{l}\text { Ig-J } \mathrm{J}_{\mathrm{H}} \\
\text { CD8APCR1 } \\
\text { AFM164ze3 } \\
\text { Mfd67 }\end{array}$ & $\begin{array}{l}0.070 \\
0.026 \\
0.036 \\
0 \cdot 118 \\
0.037\end{array}$ & $\begin{array}{l}0 \cdot 090 \\
0 \cdot 003 \\
0 \cdot 002 \\
0 \cdot 014 \\
0 \cdot 015\end{array}$ & $\begin{array}{l}32 \\
33 \\
31 \\
34 \\
35\end{array}$ \\
\hline $\begin{array}{l}\text { T cell receptor and coreceptors } \\
\alpha \text { cluster (TCRA), } \delta \text { cluster (TCRD) } \\
\beta \text { cluster (TCRB) } \\
\\
\gamma \text { cluster (TCRG) } \\
\text { CD3 } \delta, \varepsilon, \gamma(C D 3 D, C D 3 E, C D 3 G) \\
\text { CD3Z (CD3Z) } \\
\text { CD4 } \\
\text { CD8A } \\
\text { CD45 }\end{array}$ & $\begin{array}{c}7 \mathrm{p} 15-\mathrm{p} 14 \\
11 \mathrm{q} 23 \\
1 \mathrm{q} 22-\mathrm{q} 25 \\
12 \mathrm{p} 12-\mathrm{pter} \\
2 \mathrm{p} 12 \\
1 \mathrm{q} 31-\mathrm{q} 32\end{array}$ & $\begin{array}{l}\text { MYH7 } \\
\text { D7S495 } \\
\text { D7S498 } \\
\text { D7S509 } \\
\text { D7S528 } \\
\text { CD3D } \\
\text { D1S104 } \\
\text { vWF } \\
\text { CD8A } \\
\text { D1S158 }\end{array}$ & $\begin{array}{l}\text { MYH7PCR1 } \\
\text { AFM168xc3 } \\
\text { AFM183ya3 } \\
\text { AFM203wg1 } \\
\text { AFM248ve5 } \\
\text { Mfd69 } \\
\text { Mfd67 } \\
\text { vWA } \\
\text { CD8APCR1 } \\
\text { MLOW1 }\end{array}$ & $\begin{array}{l}0 \cdot 108 \\
0.037 \\
0 \cdot 025 \\
0 \cdot 085 \\
0.098 \\
0.057 \\
0 \cdot 118 \\
0.056 \\
0 \cdot 026 \\
0 \cdot 102\end{array}$ & $\begin{array}{l}0.064 \\
0.015 \\
0.014 \\
0.060 \\
0.050 \\
0.018 \\
0.014 \\
0.025 \\
0.003 \\
0.069\end{array}$ & $\begin{array}{l}36 \\
31 \\
31 \\
31 \\
31 \\
37 \\
34 \\
38 \\
33 \\
39\end{array}$ \\
\hline $\begin{array}{l}\text { Interleukins and interleukin receptors } \\
\text { IL-1 } \alpha \text { (IL1A), IL-1 } \beta \text { (IL1B), IL-1 } \\
\text { receptor (IL1R) }\end{array}$ & $2 q 12-q 21$ & D2S121 & AFM087xa 1 & 0.055 & 0.025 & 31 \\
\hline $\begin{array}{l}\text { IL-2 receptor } \beta \text { (IL2RB) } \\
\text { IL-3, IL-4, IL-5, IL-9 } \\
\text { IL-6 } \\
\text { IL-11 }\end{array}$ & $\begin{array}{c}22 \mathrm{q} 13 \\
5 \mathrm{q} 23-\mathrm{q} 31 \\
7 \mathrm{p} 21-\mathrm{p} 14 \\
19 \mathrm{q} 13.3-13.4\end{array}$ & $\begin{array}{c}\text { D22S283 } \\
\text { D5S210, FGFA } \\
\text { D5S421 } \\
\text { D7S528 } \\
\text { D19S49 }\end{array}$ & $\begin{array}{l}\text { AFM262vh5 } \\
\text { Mfd122 } \\
\text { AFM210vd6 } \\
\text { AFM248ve5 } \\
\text { Mfd11 }\end{array}$ & $\begin{array}{l}0 \cdot 081 \\
0 \cdot 021 \\
0 \cdot 093 \\
0 \cdot 098 \\
0 \cdot 122\end{array}$ & $\begin{array}{l}0 \cdot 034 \\
0.006 \\
0 \cdot 078 \\
0 \cdot 050 \\
0.054\end{array}$ & $\begin{array}{c}31 \\
4041 \\
31 \\
31 \\
42\end{array}$ \\
\hline $\begin{array}{l}\text { Autoantigens } \\
\text { Cardiac } \alpha, \beta \text { myosin heavy chain } \\
\text { (MYH6, MYH7) }\end{array}$ & $14 \mathrm{q} 11.2-\mathrm{q} 12$ & MYH7 & MYH7PCR1 & $0 \cdot 108$ & 0.064 & 36 \\
\hline $\begin{array}{l}\text { ATP-ADP carrier (ANT1) } \\
\beta_{1} \text { adrenoceptor (ADRB 1) }\end{array}$ & $\begin{array}{l}\text { 4q35-qter } \\
10 \mathrm{q} 24-\mathrm{q} 26\end{array}$ & $\begin{array}{c}\text { D4S171 } \\
\text { D10S259, D10S173, } \\
\text { D10S88 }\end{array}$ & JS8001, $\underset{\text { Mfd }}{\text { Mfd } 22}$, & $\begin{array}{l}0.061 \\
0.054\end{array}$ & $\begin{array}{l}0.016 \\
0 \cdot 060\end{array}$ & $\begin{array}{c}4344 \\
454647\end{array}$ \\
\hline & & $\begin{array}{c}\text { D10S187, D10S168 } \\
\text { D10S108 } \\
\text { D10S192 } \\
\text { D10S169 }\end{array}$ & $\begin{array}{c}\text { AFM042xe9, Mfd } 175 \\
\text { Mfd 100 } \\
\text { AFM049tc9 } \\
\text { Mfd187 }\end{array}$ & $\begin{array}{l}0 \cdot 042 \\
0 \cdot 027 \\
0 \cdot 047 \\
0 \cdot 027\end{array}$ & $\begin{array}{l}0.030 \\
0.014 \\
0.053 \\
0.024\end{array}$ & $\begin{array}{c}3147 \\
47 \\
31 \\
47\end{array}$ \\
\hline $\begin{array}{l}\text { CD antigens } \\
\text { CD1, CD48 } \\
\text { CD14, CD49B }\end{array}$ & $\begin{array}{c}1 \mathrm{q} 21.3-\mathrm{q} 23 \\
5 \mathrm{q} 22-\mathrm{q} 32\end{array}$ & $\begin{array}{c}\text { D1S104 } \\
\text { D5S210, FGFA } \\
\text { D5S421 } \\
\text { D19S49 }\end{array}$ & $\begin{array}{l}\text { Mfd67 } \\
\text { Mfd122 } \\
\text { AFM210vd6 } \\
\text { Mfd11 }\end{array}$ & & & \\
\hline $\begin{array}{l}\text { Complement components } \\
\text { r and s subcomponents } \\
\mathrm{C} 2, \mathrm{C} 4 \mathrm{~A}, \mathrm{C} 4 \mathrm{~B}, \mathrm{CH} \\
\mathrm{C} 4 \text { binding proteins } \alpha, \alpha \text {-like } 1 \text {, and } \beta \text {; } \\
3 \mathrm{~b} / 4 \mathrm{~b} \text { receptors } 1,1 \text {-like, and } 2\end{array}$ & $\begin{array}{l}12 \mathrm{p} 13 \\
6 \mathrm{p} 21.3 \\
1 \mathrm{q} 32\end{array}$ & $\begin{array}{l}\text { vWF } \\
\text { D6S265 } \\
\text { D1S158 }\end{array}$ & $\begin{array}{l}\text { vWA } \\
\text { AFM101xa1 } \\
\text { MLOW1 }\end{array}$ & & & \\
\hline
\end{tabular}

The CD antigens and complement components listed in the bottom part of the table are localised in the same chromosomal regions reported above for other genes. $\theta_{1}$ and $\theta_{2}$ represent the recombination fractions giving a lod score of -2 as evaluated by two different models (age related penetrance and "affecteds only" for the fourth generation, respectively - see text) 
ping ${ }^{45}$ as well as on published high resolution maps. ${ }^{434950}$

PCR amplifications were carried out in $50 \mu \mathrm{l}$ of a solution containing $10 \mathrm{mmol} / 1$ Tris (pH 8.0), $50 \mathrm{mmol} / 1 \mathrm{KCl}, 1.5 \mathrm{mmol} / 1 \mathrm{MgCl}_{2}$, $0.01 \%$ gelatin, $200 \mu \mathrm{mol} / 1$ each dNTP, $0.1 \mu \mathrm{mol} / 1$ both primers, $200 \mathrm{ng}$ of template DNA, and 2.5 units of Taq DNA polymerase (Perkin-Elmer), with 40 repetitions of the following cycle: 45 seconds at $94^{\circ} \mathrm{C}, 30$ seconds at the annealing temperature, and 30 seconds at $72^{\circ} \mathrm{C}$, in a Perkin-Elmer 480 Thermal Cycler. Annealing temperatures varied from 53 to $68^{\circ}$, according to the different primer pairs. PCR products were resolved by a long run on a $10-12 \%$ polyacrylamide native gel and visualised by ethidium bromide staining. All the oligonucleotides were synthesised by the ICGEB Oligonucleotide Synthesis Service on an Applied Biosystem 380B synthesiser.

\section{LINKAGE ANALYSIS}

Linkage analysis was conducted on 21 key members of the family, which is shown in the figure, panel A; this subset of the family was proven by the Simlink computer program version $4.1^{51}$ to have appropriate linkage power.

Two point linkage analyses were performed between each marker and IDC phenotype using the PC version of the MLINK option of the LINKAGE package (version 5.10). ${ }^{52}$ Analysis was carried out under the model of autosomal dominant disease with age related penetrance and the following calculated values ${ }^{11}$ : age 30 to 40 , penetrance 0.70 ; age 40 to $50,0.92$; age $>50,0.96$; persons below the age of 30 were not included in the study. No sex difference in recombination events was assumed. This model corresponds to the one suggested by Pastores et al. ${ }^{53}$

Additionally, computations were also performed according to the "affecteds only" model, by recoding the sibs of affected persons of the fourth generation as unknown.

A gene frequency of 0.0003 was calculated from a population prevalence; changes in the gene frequency of the markers made little difference in the computed lod score values.

The calculations were performed at recombination fractions of $0,0.01,0.05,0.1$, $0.2,0.3,0.4$, and 0.5 between each marker and the putative disease gene, and then further refined with a recombination fraction increment value of 0.01 in order to find the widest chromosomal region excluding linkage with a lod score value $\leq-2$. The values in $\mathrm{cM}$ were obtained by the Haldane mapping function (Utility programs for analysis of genetic linkage $\left.{ }^{54}\right)$.

\section{Results}

The linkage between IDC and 29 chromosomal markers was investigated in a large family with autosomal dominant transmission of the disease. ${ }^{3}$ The pedigree of the key members of this family, which were analysed in this work, are reported in the figure, panel $A$.

All the markers, with the exception of IGHJ containing a VNTR mapping in the immunoglobulin heavy chain gene cluster, were represented by di-, tetra-, or pentanucleotide polymorphisms (microsatellites), which were analysed by PCR amplification. All these markers were chosen for their localisation within, or very close to, candidate genes involved in the immune function. When significant lod scores were obtained only for a narrow region, more than one polymorphism was analysed for the same gene.

The immune function genes investigated, their chromosomal localisation, and the results obtained from the linkage studies are reported in the table. The figure (panels B, C, and D) shows the microsatellite amplification results obtained for markers close to the $\beta_{1}$ adrenoreceptor, the $\beta$ chain of the IL- 2 receptor, and the $\beta$ chain of the $T$ cell receptor, respectively.

A pivotal role in the normal immune function, and in its disregulation leading to autoimmunity, is played by the interaction between the $T$ cell receptor ( $T c R$ ) multicomponent complex and the HLA gene products. ${ }^{55}$ The multicomponent protein structure of $\mathrm{T}$ cells involved in this function includes the hypervariable $\alpha: \beta$ or $\gamma: \delta$ chains of the TcR (which confer antigen and HLA specificity) as well as five other invariant molecules constituting the CD3 complex $(\gamma, \delta, \varepsilon$, and the $\zeta: \zeta$ or $\zeta: \eta$ dimers) ${ }^{56}$ Furthermore, the coreceptors CD4 (in CD4 $\mathrm{T}$ cells recognising the antigen within HLA class II molecules) or CD8 (in CD8 T cells recognising the antigen within HLA class I molecules) participate in this function, together with a specific isoform of the CD45 gene product. ${ }^{56}$ All the genes encoding for these proteins were included in the list of the candidate genes in this work. The differentiation process of $T$ cells which follows antigen recognition is mediated also by the function of several soluble factors. ${ }^{57}$ Among these, the genes encoding for the two subunits of interleukin-1 (IL-1) and IL- 1 receptor, IL-2 receptor $\beta$ chain, IL-3, IL4, IL-5, IL-6, IL-9, and IL-11 were included in the study. We also investigated the loci encoding for the immunoglobulin (Ig) heavy and $\kappa$ and $\lambda$ light chains, and those encoding for the receptors for the IgA, IgE, IgG Fc fragments (which also belong to the Ig supergene family and mediate different Ig triggered functions on the target cells ${ }^{58}$ ). Finally, to test the hypothesis that some of the proteins for which autoimmune reactivity was reported in patients with IDC could be the products of specific gene alleles, we also investigated the linkage between the disease and the genes encoding for the $\beta_{1}$ adrenergic receptor, the adenine nucleotide translocator- 1 , and the cardiac $\alpha$ and $\beta$ myosin heavy chains.

For all the loci analysed, no segregation of any allele of the marker with the disease was observed (table). Lod scores were in all cases clearly negative. In order to define precisely the region of exclusion of linkage (considered as the widest region where the lod score is still equal to, or less than, -2 ), linkage analysis was performed at different recombination fractions $(\theta)$ with an increment value of $0 \cdot 1$, and sub- 
A

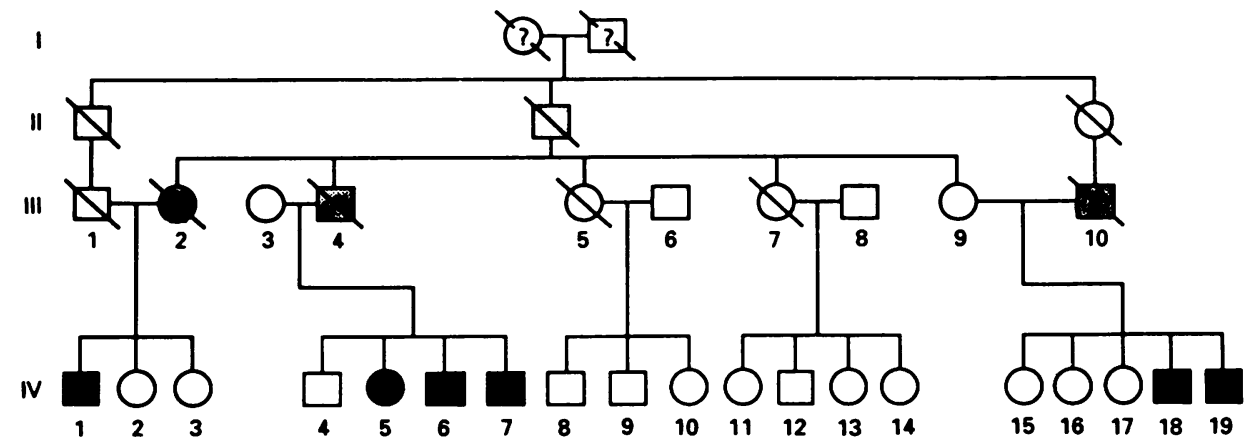

B

$A E B B \quad B C B B$ BE BC BE CE DECE BE BC BBBCBBBD ABDDABADBD

Location: 10q24-q26 ( $\beta-1$ adrenoreceptor)
Locus: D10S192

Marker: AFM049tc9

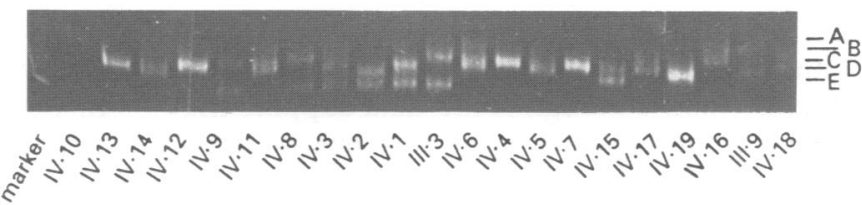

BE AC DE EG CG AE BE CF DF DF CF CD DD

DD CE EG CE

Location: $22 q 13$ (IL-2 receptor, $\beta$ chain) Locus: D22S283 Marker: AFM262vh5

D

Location: 7q35 (TCR, $\beta$-cluster)
Locus: D7S495

Marker: AFM168xc3
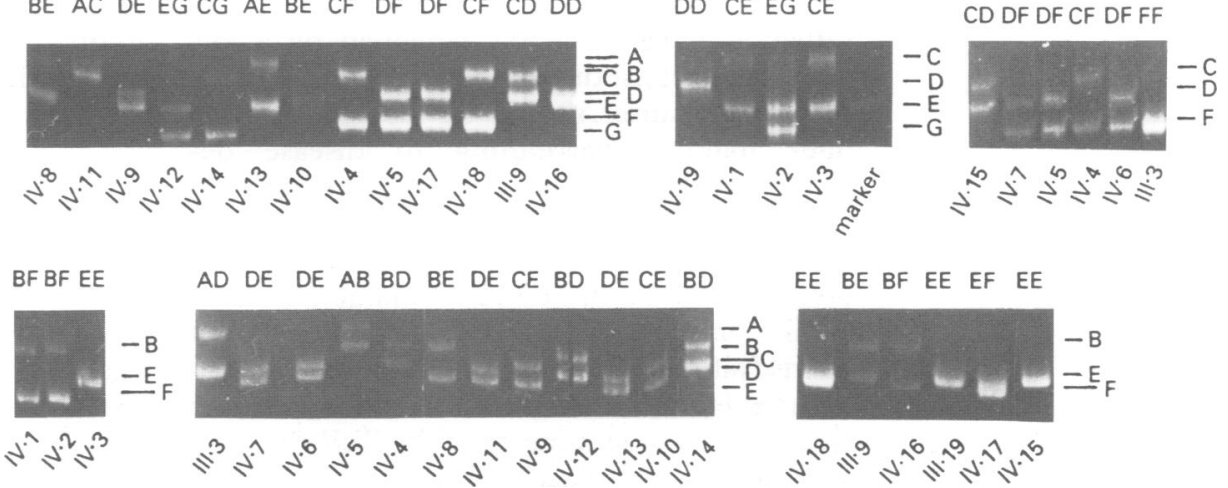

(A) Pedigree of the subset of the family used for the linkage study. Affected persons are shown by black symbols; persons dead before the beginning of the study (belonging to the third generation) in which the clinical history is strongly suggestive of IDC are shown by grey symbols. (B-D) Microsatellite amplification for selected markers. The PCR amplification products obtained for the markers indicated on the left side of the panels were resolved by gel electrophoresis, and stained with ethidium bromide. Below each lane, the family member is indicated according to the numbers reported in ( $A$ ). On the right of each picture, the position of the different alleles identified is indicated by letters (arbitrarily chosen). On top of each lane, the genotype of each person is shown.

sequently of $0 \cdot 01$. The results were interpolated and the recombination fractions yielding a lod score of exactly $-2 \cdot 0$ are reported in the table, column $\theta_{1}$. No one of the markers investigated is linked to the disease in this family in a range of $\theta$ equal to 0.026 to 0.122 on both sides of the markers, which corresponds to a total genetic distance of 5 to $28 \mathrm{cM}$. Furthermore, in the possibility that sibs of affected subjects in the fourth generation could be affected at any age, the values of recombination fractions with a lod score of -2 under the "affecteds only" model were also evaluated (table, column $\theta_{2}$ ). No linkage could be detected in this case either (although with a more conservative magnitude of exclusion).

These results indicate that in this family the involvement of the investigated genes in the pathogenesis of IDC can be ruled out.

Furthermore, some of the investigated markers map in chromosomal regions containing several other genes coding for proteins involved in some immunological functions. These genes, and the corresponding chromosomal markers, are listed in the bottom part of the table. They include white cell differentiation antigens, such as CD1 and CD48 in 1q21.3-q23, CD9 in 12p12-pter, CD14, CD49 in 5q22-q32, CD28 in $19 \mathrm{q} 13.3$, and several complement components and receptors. The involvement of these genes in the development of IDC in this family can also be excluded.

\section{Discussion}

The presence of autoimmune reactivities (namely the production of antibodies or reactive $T$ cell clones against self antigens) has often been invoked to explain the pathogenetic mechanisms underlying several diseases of unknown aetiology, including IDC. These studies are based on the presence of organ specific antibodies or $\mathrm{T}$ cells reacting against different self antigens, ${ }^{1-21}$ and on association studies indicating an increased frequency of some HLA haplotypes (mainly including the DR4 allele $)^{23-26}$ or TcR polymorphisms ${ }^{59}$ in patients with IDC. Altogether, these data suggest that the inappropriate presentation of foreign antigens (possibly of viral origin) or abnormal self antigens could lead to an aberrant form of activation of cells of the immune system, with consequent autoimmune reactivity against myocardial cells. 
In this work, we have investigated the segregation of alleles of several candidate genes involved in the immune function with IDC in a large Italian family by using highly informative microsatellite repeats. Segregation of the disease within this family is consistent with a model of autosomal dominant transmission with age related penetrance. ${ }^{311}$

The analysis of allele segregation for the $6 \mathrm{p} 21.3$ region, containing the $3 \mathrm{Mb}$ area encompassing class I and class II HLA loci, is consistent with the exclusion of linkage of this region with the disease. Similarly, exclusion of linkage to HLA was also recently obtained in other diseases of suspected autoimmune aetiology, such as Graves's disease and Hashimoto's thyroiditis.$^{60}$ It should be considered, indeed, that, although some data support the direct participation of class II genes in autoimmune disease susceptibility, most persons with disease associated class II alleles do not develop autoimmune disease. ${ }^{61}$ This observation, which can be explained by a low penetrance of the disease, nevertheless suggests that other causes should be identified as the ones mainly contributing to disease development. According to this view, the association of IDC with some HLA, Gm, or TcR haplotypes could represent a marker of more severe forms of the disease, characterised by earlier onset and accelerated progression of heart dysfunction. ${ }^{27}$

In the family investigated, the genes encoding for structural components of the TcR (TCRA, TCRB, TCRG, TCRD, and the D, E, G, W, and $Z$ chains of $C D 3$ ) and associated proteins (CD4, CD8, CD45) all failed to show linkage. The total region of exclusion of linkage ranged from 12 to $27 \mathrm{cM}$ for all the loci tested, with the exception of CD8, where a significant value of exclusion was obtained only at $2.6 \mathrm{cM}$ on each side of the marker; in this case, however, the marker was chosen to be intragenic. Also, for the TcR genes, association studies have been conducted in several autoimmune diseases, ${ }^{62}$ including IDC. ${ }^{59}$ However, the overall outcome of these studies is difficult to evaluate, ${ }^{63}$ possibly because of the limited polymorphism of the markers investigated. ${ }^{62}$

Other genes, coding for several mediators of $T$ cell function such as IL- 1 and IL- 1 receptor, IL-2 receptor $\beta$ chain, IL-3, IL-4, IL-5, IL-6, IL-9, and IL-11, are clearly not linked to IDC in this family. Similarly, negative results were also obtained for genes possibly involved in humoral autoimmunity (such as the Ig heavy and light chain genes, and the genes encoding the Ig Fc fragment receptors), and for genes which were indicated as major autoantigens $\left(\beta_{1}\right.$ adrenoreceptor, adenine nucleotide translocator-1, and cardiac $\alpha$ and $\beta$ myosin heavy chains) (table). The gene for the $\beta_{1}$ receptor was tested with eight polymorphic PCR markers as it maps to 10q24-26; its recent localisation to a narrower region ${ }^{45}$ makes the exclusion of linkage to the gene even more evident, as loci D10S88, D10S259, D10S173, D10S187, and D10S192 are all in close proximity to the gene. ${ }^{3145}$ The gene for the adenine nucleotide translocator-1 is located at $4 \mathrm{q} 35$-qter, closely linked to locus D4S171, where the microsatellite marker is also mapped. ${ }^{4344}$ The less informative results were obtained when testing the gene for IGLK. However, since recent mapping data define the localisation of IGLK on chromosome 2 about $2 \mathrm{Mb}$ apart from $\mathrm{CD} 8,{ }^{64}$ the $\kappa$ light immunoglobulin gene cluster can also be excluded from being involved in the development of IDC. The lack of association of these genes with IDC in the family investigated is not surprising, since the data on the serological reactivities against myocardial antigens, although of considerable interest, should be considered primarily phenomenological, ${ }^{6566}$ and are unable to provide support for an aetiological role of these antibodies in disease development. ${ }^{2267}$

In conclusion, taken altogether, these data exclude, at least in the large family examined, the linkage of candidate genes involved in immune reactivity with disease transmission. It is likely that only the extension of linkage studies to other regions of the genome will eventually lead to the identification of the gene primarily involved in the development of IDC.

We are very grateful to Oscar Burrone for helpful discussions and suggestions, to Jurg Ott for the programs used for computer calculations, to Fabrizio d'Adda di Fagagna for his help in the use of the software and hardware computer facilities at ICGEB, to Jen-i-Mao for the unpublished primer sequences for the JS8001 marker, to Jean Weissenbach and Susan Cure for the work. MK is a fellow of Amici del Cuore, Trieste. GMS is work. MK is a fellow of Amici del Cuore, Trieste. GMS is
supported by the grant "Nerina Vera Kreilshein Wagner" of the supported by the grant "Nerina Vera Kreilshein Wagner" of the
Fondazione Buzzati-Traverso. This work was partially supported by the Telethon grant no E-11.

1 Brandeburg RO, Chazov E, Cherian G, et al. Report of the WHO/ISFC task force on the definition and classification of the cardiomyopathies. Circulation 1981;64:437-8A.

2 Codd MB, Sugrue DD, Gersh BJ, Melton LJ. Epidemiology of idiopathic dilated and hypertrophic cardiomyopathy. A population-based study in Olmsted County, Minnesota 1975-1984. Circulation 1989;80:564-72.

3 Mestroni L, Miani D, Dilenarda A, et al. Clinical and pathologic study of familial dilated cardiomyopathy. $\mathrm{Am}$ $\mathcal{f}$ Cardiol 1990;65:1449-53.

4 Lilienfeld DE, Sprafka JM, Pham DL, Baxter J. Morbidity from congestive and hypertrophic cardiomyopathy in the Minneapolis-St. Paul metropolitan area: 1979-1984. Cardiology 1992;80:71-6.

5 Schofield PM. Indications for cardiac transplantation. $\mathrm{Br}$ Heart $\mathcal{F}$ 1991;65:55-6.

6 McManus B, Kandolf R. Evolving concepts of cause, consequence, and control in myocarditis. Curr Opin Cardiol 1992;6:418-27.

7 Jin O, Sole MJ, Butany JW, et al. Detection of enterovirus RNA in myocardial biopsies from patients with myocarditis and cardiomyopathy using gene amplification by ocarditis and cardiomyopathy using gene amplification by polymerase chain reaction Cimculation 1990:82:8-16.

8 Weiss LM, Liu XF, Chang KL, Billingham ME. Detection of enteroviral RNA in idiopathic dilated cardiomyopathy and other human cardiac tissues. $\mathcal{F}$ Clin Invest 1992;90: 156-9.

9 Severini GM, Mestroni L, Falaschi A, Camerini F, Giacca $M$. Nested polymerase chain reaction for high-sensitivity detection of enteroviral RNA in biological samples. $\mathcal{f}$ Clin Microbiol 1993;31:1345-9.

10 Manolio TA, Baughman KL, Rodeheffer R, et al. Prevalence and etiology of idiopathic dilated cardiomyopathy (summary of a National Heart, Lung and Blood Institute Workshop). Am f Cardiol 1992;69:1459-66.

11 Mestroni L, Krainovic M, Severini GM, et al. Familial dilated cardiomyopathy. $B r$ Heart $\mathcal{f}$ (in press).

12 Anderson JL, Carlquist JF, Hammond EH. Deficient natural killer cell activity in patients with idiopathic dilated cardiomyopathy. Lancet 1982;2:1124-7.

13 Gerli R, Rambotti P, Spinozzi F, et al. Immunologic studies of peripheral blood from patients with idiopathic dilated cardiomyopathy. Am Heart $\mathcal{f} 1986 ; 112: 350-5$.

14 Wong CY, Woodruff JJ, Woodruff JFR. Generation of cytotoxic T-lymphocytes during Coxsackie B3 infection. II. totoxic T-lymphocytes during Coxsackie B3 infection. II. Characterization of effector cells and demonstration of
cytotoxicity against viral-infected myofibers. 7 Immunol cytotoxicity agains

15 Caforio ALP, Bonifacio E, Stewart JT, et al. Novel organspecific circulating cardiac autoantibodies in dilated cardiomyopathy. $\mathcal{F}$ Am Coll Cardiol 1990;15:1527-34. 
16 Caforio ALP, Grazzini M, Mann JM, et al. Identification of a- and b-cardiac myosin heavy chain isoforms as major autoantigens in dilated cardiomyopathy. Cinculation 1992; 85: $1734-42$.

17 Limas CJ, Goldenberg IF, Limas C. Autoantibodies against b-adrenoreceptors in human idiopathic dilated cardiomyopathy. Circ Res 1989;64:97-103.

18 Magnusson Y, Marullo S, Hoyer S, et al. Mapping of a functional autoimmune epitope on the $b_{1}$-adrenergic receptor in patients with idiopathic dilated cardiomyopathy. $\mathcal{f}$ Clin Invest 1990;86:1658-63.

$19 \mathrm{Fu} \mathrm{LX}$, Magnusson Y, Bergh CH, et al. Localization of a functional autoimmune epitope on the muscarinic acetylfunctional autoimmune epitope on the muscarinic acetyl-
choline receptor-2 in patients with idiopathic dilated carcholine receptor-2 in patients with idiopathic
diomyopathy. $\mathcal{F}$ Clin Invest 1993;91:1964-8.

20 Klein R, Maisch B, Kochsiek K, Berg PA. Demonstration of organ-specific antibodies against heart mitochondria (anti-M7) in sera from patients with some forms of heart diseases. Clin Exp Immunol 1984;58:283-92.

21 Schulteiss HP, Bolte HD. Immunological analysis of autoantibodies against the adenine nucleotide translocator in dilated cardiomyopathy. $\mathcal{F}$ Mol Cell Cardiol 1985;17: 603-17.

22 Neu N, Ploier B, Ofner C. Cardiac myosin-induced myocarditis-heart antibodies are not involved in the induction of the disease. I Immunol 1990;145:4094-100.

23 Carlquist JF, Menlove RL, Murray MB, O'Connell JB, Anderson JL. HLA class II (DR and DQ) antigen associations in idiopathic dilated cardiomyopathy. Validation study and meta-analysis of published HLA association studies. Circulation 1991;83:515-22.

24 Limas CJ, Limas C. HLA antigens in idiopathic dilated cardiomyopathy. Br Heart $\mathcal{f} 1989 ; 62: 379-83$.

25 Arbustini E, Gavazzi A, Pozzi R, et al. The morphologic spectrum of dilated cardiomyopathy and its relation to spectrum of dilated cardiomyopathy and its relation to

26 Zerbe TR, Kaufmann C, Colson Y, Duquesnoy R. Associations of HLA-A, B, DR antigens with primary disease in cardiac allograft recipients. Am $\mathcal{F}$ Cardiol 1988;61: 1359-61

27 Martinetti M, Dugoujon JM, Caforio ALP, et al. HLA and immunoglobulin polymorphism in idiopathic dilated cardiomyopathy. Hum Immunol 1992;35:193-9.

28 Michels VV, Moll PP, Miller FA, et al. The frequency of familial dilated cardiomyopathy in a series of patients with idiopathic dilated cardiomyopathy. N Engl $\mathscr{f}$ Med 1992; 326:77-82.

29 Sambrook J, Fritsch EF, Maniatis T. Molecular cloning. $A$ laboratory manual. 2nd ed. Cold Spring Harbor, NY: Cold Spring Harbor Laboratory Press, 1989.

30 Neitzel $\mathrm{H}$. A routine method for the establishment of permanent growing lymphoblastoid cell lines. Hum Genet manent growing

31 Weissenbach J, Gyapay G, Dib C, et al. A second-generation linkage map of the human genome. Nature 1992;359: linkage

32 Decorte R, Cuppens H, Marynen P, Cassiman JJ. Rapid detection of hypervariable regions by the polymerase chain reaction techniques. DNA Cell Biol 1990;9:461-9.

33 Human Gene Mapping 11. Cytogenet Cell Genet 1991;58: 1685.

34 Weber JL, Kwitek AE, May PE. Dinucleotide repeat polymorphism at the D1S104. Nucleic Acids Res 1990;18:2835.

35 Levitt RC, Jedlicka AE, Nouri N. Dinucleotide repeat polymorphism at the hormone sensitive lipase (LIPE) locus. Hum Mol Genet 1992;1:139.

36 Human Gene Mapping 11. Cytogenet Cell Genet 1991;58: 1675.

37 Weber JL, Kwitek AE, May PE. Dinucleotide repeat polymorphism at the D11S419 and CD3D loci. Nucleic Acids Res 1990;18:4036.

38 Kimpton C, Walton A, Gill P. A further tetranucleotide repeat polymorphism in the vWF gene. Hum Mol Genet 1992;1:287.

39 Overbeck LD, Weston MD, Kimberling WJ, Johnson DH. A new highly polymorphic dinucleotide (CT)n repeat polymorphism D1S158 on chromosome $1 \mathrm{q}$ isolated by microdissection. Hum Mol Genet 1992;1:141.

40 Human Gene Mapping 11. Cytogenet Cell Genet 1991;58: 1668.

41 Jaye XLM, Crumley G, Jabs EW. Dinucleotide repeat polymorphism in the human fibroblast growth factor acidic (FGFA) gene on chromosome 5. Hum Mol Genet 1992, 1:216.

42 Weber JL, May PE, Kappel C. Dinucleotide repeat poly- morphism at the D19S49 locus. Nucleic Acids Res 1990; 18:1927.

43 Haraguchi Y, Chung AB, Torroni A, et al. Genetic mapping of human heart-skeletal muscle adenine nucleotide translocator and its relationship to the facioscapulohumeral muscular dystrophy locus. Genomics 1993;16:479-85.

44 Weber JL, May PE. Dinucleotide repeat polymorphism at the D4S171. Nucleic Acids Res 1990;18:2202.

45 Group NCM. A comprehensive genetic linkage map of the human genome. Science 1992;258:67-86.

46 Hudson TJ, Engelstein M, Lee MK, et al. Isolation and chromosomal assignment of 100 highly informative human simple sequence repeat polymorphisms. Genomics 1992; 13:622-9.

47 Decker RA, Moore J, Ponder B, Weber JL. Linkage mapping of human chromosome 10 microsatellite polymorphisms. of human chromosome 10

48 Human Gene Mapping 11. Cytogenet Cell Genet 1991;58 5-102.

49 Todd S, Sherman SL, Naylor SL. Dinucleotide repeat loci contribute highly informative genetic markers to the human chromosome 2 linkage map. Genomics 1993;16: 612-18.

50 Warrington JA, Bailey SK, Armstrong E, et al. A radiation hybrid map of 18 growth factor, growth factor receptor, hormone receptor, or neurotransmitter receptor genes on the distal region of the long arm of chromosome 5. Genomics 1992;13:803-8.

51 Ploughmanman LM, Boehnke M. Estimating the power of a proposed linkage study for a complex genetic trait. $\mathrm{Am}$ F Hum Genet 1989;44:543-51.

52 Lathrop GM, Lalouel JM, Julier C, Ott J. Proc Natl Acad Sci USA 1984;74:1245-9.

53 Pastores GM, Michels VV, Schaid DJ, et al. Search for the gene defect in familial idiopathic dilated cardiomyopathy preliminary report of an exclusion map. HGM11. Cy togenet Cell Genet 1991

54 Ott J. Map distance. In: Analysis of human genetic linkage. Revised edition. Baltimore: Johns Hopkins University Press, 1991:6-11

55 Rothbard JB, Gefter ML. Interactions between immunogenic peptides and MHC proteins. Annu Rev Immunol 1991;9:527-67.

56 Janeway CAJ. The $\mathrm{T}$ cell receptor as a multicomponent signaling machine: CD4/CD8 coreceptors and CD45 in T cell activation. Annu Rev Immunol 1992;10:645-74.

57 Ullman KS, Northrop JP, Verweij CL, Crabtree GR. Transmission of signals from the $T$ lymphocyte antigen receptor to the genes responsible for cell proliferation and immune function: the missing link. Annu Rev Immunol 1990;8: 421-52.

58 Ravetch JV, Kinet JP. Fc receptors. Annu Rev Immunol 1991; 9:457-92.

59 Limas C, Limas CJ, Boudoulas H, Graber H, Bair R, Sparks $\mathrm{L}$, Wooley CF. T-cell receptor gene polymorphisms in familial cardiomyopathy: correlation with anti- $\beta$-receptor autoantibodies. Am Heart $\mathcal{F}$ 1992;124:1258-63.

60 Roman SH, Greenberg D, Rubinstein P, Wallenstein S Davies TF. Genetics of autoimmune thyroid disease: lack of evidence for linkage to HLA within families. $f$ Clin Endocrinol Metab 1992;74:496-503.

61 Todd JA, Acha-Orbea H, Bell JI, et al. A molecular basis for MHC class II-associated autoimmunity. Science 1988 240:1003-9.

62 Moss PAH, Rosenberg WMC, Bell JI. The human T cell receptor in health and disease. Annu Rev Immunol 1992; 10:71-96.

63 Hillert J, Olerup O. Germ-line polymorphism of TCR genes and disease susceptibility-fact or hypothesis. Immunol Today 1992;11:47-9.

64 Weichhold GM, Huber C, Parnes JR, Zachau HG. The CD8a locus is located on the telomere side of the immunoglobulin $\mathrm{k}$ locus at a distance of $2 \mathrm{Mb}$. Genomics 1993;16:512-14.

65 Bender JR. Idiopathic dilated cardiomyopathy: an immunologic, genetic, or infectious disease, or all of the above? Circulation 1991:83:704-5.

66 Möller E, Böhme J, Valugerdi MA, Ridderstad A, Olerup $O$. Speculations on mechanisms of HLA associations with autoimmune diseases and the specificity of "autoreactive" T lymphocytes. Immunol Rev 1990;118:5-19.

67 Möller E, Ström H, Al-Balaghi S. Role of polyclonal activation in specific immune responses. Relevance for findings of antibody activity in various diseases. Scand $f$ Immunol 1980;12:177-85. 